Egyptian Journal of Aquatic Biology \& Fisheries

Zoology Department, Faculty of Science,

Ain Shams University, Cairo, Egypt.

ISSN $1110-6131$

Vol. 25(1): 389 - 405 (2021)

www.ejabf.journals.ekb.eg

\title{
An integrating geospatial technology with microbiology in isolating and characterizing selenite-reducing bacteria from two mangrove areas along the Red Sea, Egypt \\ Soad H. Shatla ${ }^{1}$, Sameh B. El Kafrawy ${ }^{2}$, Hala A. Ahmed ${ }^{1}$, and Mehreshan T. El- mokadem ${ }^{1}$ \\ 1. Botany Department, Women College for Arts, Science and Education, Ain Shams University, Cairo, Egypt \\ 2. Department of Marine Sciences, National Authority for Remote Sensing and Space Sciences \\ (NARSS), Egypt \\ "Corresponding Author: S_elkafrawy@yahoo.com
}

\section{ARTICLE INFO}

Article History:

Received: Nov. 1, 2020

Accepted: Jan. 19, 2021

Online: Jan. 26, 2021

Keywords:

Avicennia marina; selenite reducing bacteria; Cobetia amphilecti; digital elevation model; drainage network; Vibrio alginolyticus

\begin{abstract}
The wide anthropogenic use of selenium compounds represents the major source of selenium pollution worldwide causing environmental problems and health concerns. The current study aimed at isolating sixteen bacterial strains, capable of transforming toxic SeO32- to non-toxic elemental selenium, from sediment, water, and mangrove leaves in two mangrove study areas $(17 \mathrm{~km}$ south of Safaga and $35 \mathrm{~km}$ north of Quseir). Geospatial technology was used to detect the location of the mangrove areas. Microbes were isolated using membrane filter technique and direct bacterial plating on salt peptone (SP) agar supplemented with $5 \mathrm{mM}$ sodium selenite. Morphological, biochemical, Scanning Electron Microscope (SEM), and Transmission Electron Microscope (TEM) analysis of two bacterial isolates were identified using 16S rRNA gene sequencing. Results showed that the red colonies of sixteen isolates signify the reduction of selenite to red elemental selenium. Phylogenetic analysis proved that the two tested isolates affiliated to (Cobetia amphilecti and Vibrio alginolyticus) with accession numbers of MN099349 and MN099350 respectively. SEM and TEM analysis confirmed the presence of globular particles of insoluble selenium outside and inside the cells of the two selected bacteria. The higher bacterial count in south Safaga compared with wadi Abu Hamrah ensured by drainage pattern which shows that there are main drains that pour directly in mangrove stand especially in south Safaga stand. In conclusion, bacterial isolates can transform toxic selenite to nontoxic red elemental selenium which could be further used for bioremediation of contaminated locations. To our knowledge, these selenite reducing bacteria were not detected and /or isolated from the Egyptian Red Sea coast before as well as both identified strains are novel and well-characterized bacterial aerobic selenite reductase.
\end{abstract}

\section{INTRODUCTION}

In 1817, Berzelius discovered Selenium (Se) (Montes, 2012) in several natural and anthropogenic sources (Savard et al., 2009). Selenium occurs in four states; $\left[\mathrm{SeO}_{4}{ }^{-2}\right]$, selenite $\left[\mathrm{SeO}_{3}{ }^{-2}\right]$, selenide $\left(\mathrm{Se}^{-2}\right)$, and elemental selenium $\left[\mathrm{Se}^{0}\right]$ (Rehan et al., 2018). Though humans require trace quantities of selenium for cellular functions, elemental 
selenium and selenite oxyanions are lethal in even small dosages (Fordyce, 2005). Due to the human activities, selenium contamination is considered to be the main environmental pollution found almost everywhere (soil, water) (David et al., 2015) Selenium has widespread uses in industrial and agricultural processes, which are responsible for its high toxic levels in the environment (Pierru et al., 2006).

Microorganisms have been shown to play major role in the reduction of different $\mathrm{Se}$ oxyanions (Nancharaiah and Lens, 2015). Moreover, selenium bio-reduction mechanism has attracted attention to be used for remediation of selenium oxyanionscontaminated sites (Gonzalez-Gil et al., 2016).

Both halophilic and halotolerant microorganisms are suitable for biomineralization in saline soils because they have several adaptation mechanisms (Ventosa, 2004), and can produce many functional compounds as extracellular, hydrolytic enzymes that are used in biomedical science and chemical industries (Chen and Liu., 2013).They are distributed widely in hypersaline environments, all over the phyla and the orders of bacterial domain (Hedi et al., 2009), and classified into three groups: slightly halophiles, moderately halophiles and extremely halophiles with optimum $\mathrm{NaCl}$ concentration of 2-5, 5-20, and 20-30\%, respectively according to their response to $\mathrm{NaCl}$ (Kerkar, 2004).

Mangrove ecosystems occur in the transitional area between marine and terrestrial environments (Thi $\boldsymbol{e t}$ al., 2014) that are rich in marine microorganisms and unique halophilic flora. The ecosystem importance originates from its protection of coastal zones from corrosion and its contribution of recycling nutrients in wetland environments (Twilley et al., 1992). In Egypt, Avicennia marina (black mangrove) and Rhizophora mucronata (red mangrove) (Basheer et al., 2019) inhabit many sites along the Sinai Peninsula and the Red Sea shoreline.

Remote sensing used for mapping mangroves (including biomass and carbon stocks) saving time and money and at a wider scale than field measurements (Pham et al., 2019). The current study aimed at applying geospatial technology in detecting the mangrove ecosystem areas along the Red Sea from which halophilic microorganisms capable of transforming toxic SeO32- to non-toxic elemental selenium were isolated.

\section{MATERIALS AND METHODS}

\section{Study area}

Two mangrove areas along the Red Sea were selected for the current study (Figure 1). The first one is located $17 \mathrm{Km}$ south of Safaga (26 37' 01.04"N and 34 00' 39.96" E ) whereas the second one is located $35 \mathrm{~km}$ north of Quseir (Wadi Abu Hamrah) $\left(26^{\circ} 23^{\prime}\right.$ 58.04"N and 34 $\left.07^{\circ} 01.19^{\prime \prime} \mathrm{E}\right)$.

\section{Sampling}

The study collected samples of water, sediment, and mangrove leaves from the two mangrove study areas during November 2018. From each area, two samples of water (500 ml; depth $20 \mathrm{~cm}$ ) were collected and then mixed thoroughly to make one composite sample. Moreover, the study collected two groups of leaves for microbial variation detection. The first group was five leaves from different plants and the second from different heights of one plant. Finally, two sediment samples (depth $40 \mathrm{~cm}$ ) were collected using a plastic coring tube of $25 \mathrm{~cm}$ in diameter and $10 \mathrm{~cm}$ in length. All 
samples were immediately placed in ice sterilized bags and brought to the laboratory where they were kept in a refrigerator at $4^{\circ} \mathrm{C}$ until they were processed and analyzed in the laboratory within 24-48h.
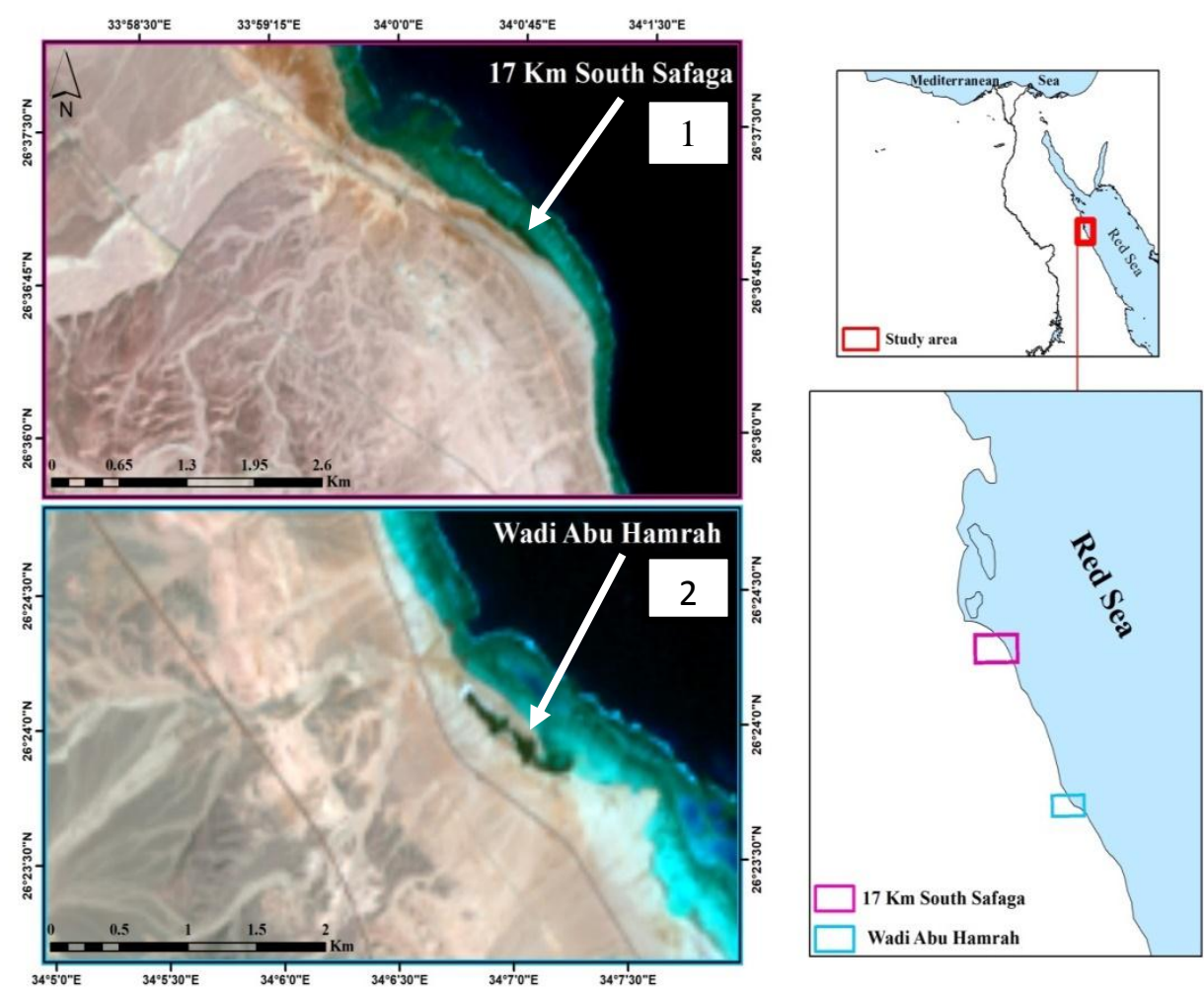

Fig. 1: The two study areas along the Red Sea, location 1 (17Km Sough Safaga) and location 2 (Wadi Abou Hamrah)

\section{Isolation and purification of selenium reducing bacteria:}

The bacteria were isolated using direct plating technique method in salt peptone agar medium (SP; g/l), that contained $\mathrm{KCl} 0.5 ; \mathrm{MgSO}_{4} .7 \mathrm{H}_{2} \mathrm{O}, 1 ; \mathrm{CaCl}_{2} .3 \mathrm{H}_{2} \mathrm{O}, 0.7$; $\mathrm{MnCl} .4 \mathrm{H}_{2} \mathrm{O}$, 0.05; Peptone, 10; Yeast extract, 10; Agar, 15 (Williams et al., 1989) and nutrient agar medium (NA; g/l) that contained Peptone, 5.0; $\mathrm{NaCl}, 3.0$; beef extract, 3.0; agar , 18 (Mishra et al ., 2011) with 1-5\% NaCl (w/v) at $\mathrm{pH} \mathrm{7.0 \pm 2.} \mathrm{Both} \mathrm{media}$ were supplemented with $5 \mathrm{mM}$ selenite then incubated at $30{ }^{0} \mathrm{C}$ under aerobic conditions for $72 \mathrm{~h}$.

Orange, pink and red colonies, indicating that the isolates could reduce selenite to elemental selenium; they were re-streaked on nutrient agar and salt peptone media without selenite to confirm that the color was not due to pigmentation. The pure cultures were isolated and maintained on selenite supplemented plates until use (Mishra et al., 2011). 


\section{Enumeration of metalloid-resistant bacteria}

For enumeration of the isolated selenite reducing bacteria, one gram of the collected leaves of Avicennia marina and / or sediment samples were transferred to $100 \mathrm{ml}$ sterile saline solution in $250 \mathrm{ml}$ Erlenmeyer's flask. The flask, contexts were mixed thoroughly in the shaker for 5 minutes then filtered using Millipore filtration technique (APHA, 1995). Sea water samples were filtered using the same filtration technique. The Millipore filter paper was cultured on the surface of SP and/ or NA agar plates. The plates were incubated at $30^{\circ} \mathrm{C}$ for $72 \mathrm{hr}$. for counting the colony forming unit (CFU) and used to calculate counts / g. of the leaves and sediment and per $\mathrm{ml}$ of water samples. Two media used for the enumeration; salt peptone agar medium (SP), (Williams et al., 1989). and nutrient agar medium (NA) (Mishra et al., 2011) supplemented with 1 and/ or $5 \% \mathrm{NaCl}$ and with and without $5 \mathrm{mM}$ sodium selenite.

\section{Characterization of the bacterial isolates:}

Identification of $\mathrm{Na}_{2} \mathrm{SeO}_{3}$ tolerant bacteria was done based on morphological characterization and biochemical test following Williams et al. (1989).

\section{Factors influencing selenite reducing bacterial growth}

To determine the optimum temperature and $\mathrm{pH}$ for the growth of the strain, the cultures were incubated at a temperature range of $15-50{ }^{\circ} \mathrm{C}$ with intervals of $5{ }^{\circ} \mathrm{C}$ and $\mathrm{pH}$ values of 5-10.5. Also, growth of the strains were evaluated at different percentage of $\mathrm{NaCl}$ values $(0-30 \% \mathrm{NaCl})$ by using Luria Bertani broth medium (LB; g/l), that contained bacteriological peptone, 10; yeast extract, 5.0; NaCl, 5.0 supplemented with $5 \mathrm{mM}$ selenite under aerobic conditions (Khalilian et al., 2015). $\mathrm{pH}$ values were adjusted by 0.1 and $1 \mathrm{~N} \mathrm{HCl}$, and 0.1 and $1 \mathrm{~N} \mathrm{NaOH}$.

\section{Phylogenetic analysis}

The two selected isolates (one moderate halophile and one halotolerant) were identified using 16S rRNA sequencing. The obtained gene sequence was searched in Basic Local Alignment Search Tool (BLAST) and online interactive Tree Of Life (iTOL) tool was used for phylogenetic tree construction (Letunic and Bork, 2006). The sequence was submitted to National Center for Biotechnology Information (NCBI) and the accession number was obtained.

Transmission electron microscopy (TEM) and scanning electron microscopy (SEM) analysis to determine selenium particle within isolate cell

TEM and SEM observations were carried out according to Zhang $\boldsymbol{e t}$ al. (2018) to study the location of Se reduced by the bacterial strains (Cobetia amphilecti and Vibrio alginolyticus).

\section{Analytical analysis \\ Determination Total Dissolved Selenium (TDSe)}

Total dissolved selenium (TDSe) was determined in the three samples collected (sediment, water and leaves) from mangrove ecosystem, Red Sea, using spectroscopic method according to the method of APHA (2017). 


\section{Statistical analysis}

The study computed correlation analysis with $\mathrm{p}$-value $<0.05$ using $\mathrm{R}$ programming language. The multivariate clustering analysis was done using ClustVis online tool (Metsalu and Vilo, 2015).

\section{Digital elevation model}

According to Sarika (2005), rainfall is the major source of trace metals into the mangrove. Hence, it is important to extract the drainage pattern of the two study areas to detect the area that may receive the higher content of selenium. Consequently, the study used Digital Elevation Model (DEM) for deriving the drainage network along South Safaga and Wadi Abu Hamrah. DEM, the digital representation of the earth surface terrain (Balasubramanian, 2017), was obtained from Shuttle Radar Topography Mission (SRTM) data available at the United States Geological Survey website (USGS), with 30 $\mathrm{m}$ spatial resolution. Different processes were carried out for the extraction of drains including clipping the boundary of the study area, creating a flow direction raster by using flow direction and flow accumulation, deriving of stream, and stream order using ArcGIS 10.1.

\section{RESULTS AND DISCUSSION}

The current study isolated two novel gram-negative, selenite-reducing bacteria, Cobetia amphilecti and Vibrio alginolyticus. These bacteria converted selenite to elemental selenium ( $\mathrm{Se}^{0}$; red colored colonies).

\section{Isolation and purification of selenite reducing bacteria}

Isolation of the moderately halophiles resistant to selenite was performed using a culture medium maintaining rapid bacterial growth. Altogether 16 bacterial isolates were isolated from sediment, water and leaves samples collected from the mangrove forest, Red Sea, Egypt, using SPA and NA media supplemented with and/ or $5 \mathrm{mM}$ sodium. Appearance of reddish color after 24-48 $\mathrm{h}$ indicated that selenite reducing bacteria has been enriched which converted soluble selenite $\left(\mathrm{Na}_{2} \mathrm{SeO}_{3}\right)$ into red colored elemental selenium $\left(\mathrm{Se}^{0}\right)(\mathrm{A})$ when compared to control plate which failed to show a change in color when incubated under same conditions (B) (Fig. 2).

\section{Reduction of Selenite:}

Microorganisms can carry out the conversion of $\mathrm{SeO}_{3}{ }^{2-}$ to $\mathrm{Se}^{0}$ via several mechanisms (Kessi, 2006). $\mathrm{SeO}_{3}{ }^{2-}$ reduction can be catalyzed by reductases, including the periplasmic nitrite reductase, sulfite reductase, and dimethyl sulfoxide (DMSO) reductase (Afkar $\boldsymbol{e} t$ al., 2003). Several thiol mediated reactions have also been observed to reduce selenite to elemental selenium (Nancharaiah and Lens, 2015). 


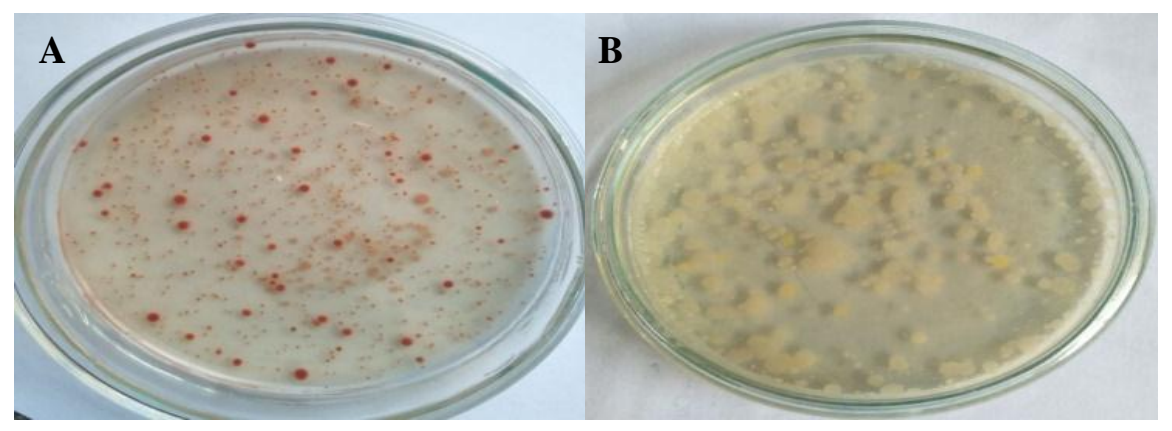

Fig.(2): (A) The formation of red colonies in presence of sodium selenite, (B) colorless colonies in absence of sodium selenite

\section{Enumeration of bacteria}

Culturable bacterial populations of leaves, water, and sediment samples of Avicennia marina ecosystem were enumerated. The results in table (1) indicated generally high counts for halophilic bacteria in location 1 comparing with those from location 2 of the mangrove area. This high count might be attributed to the high nitrogen and carbohydrate contents of the leaves of Avicennia marina plant from the same site (Khalaf, 2002).

Table (1): The total bacterial counts in water (ml), sediment (gm) and leaf of dry weight of Avicennia marina at two sites. Both count in SP containing $5 \mathrm{Mm}$ sodium selenite and $5 \% \mathrm{NaCl}$

\begin{tabular}{|ccc|}
\hline Samples & location 1 & location 2 \\
\hline Sediment & 117 & 6 \\
\hline Water & 100 & 68 \\
\hline Leaves & 70 & 9 \\
\hline
\end{tabular}

The correlation analysis between count of water, sediment, and leaves revealed a high positive correlation (direct proportion, dark blue) between leaves and sediment count and weak positive (faint blue) correlation between both leaves and sediment with water at pvalue of 0.05 (Figure 3a). The correlation network revealed that leaves stand as a key link between water and sediment (Figure $3 b$ ). 

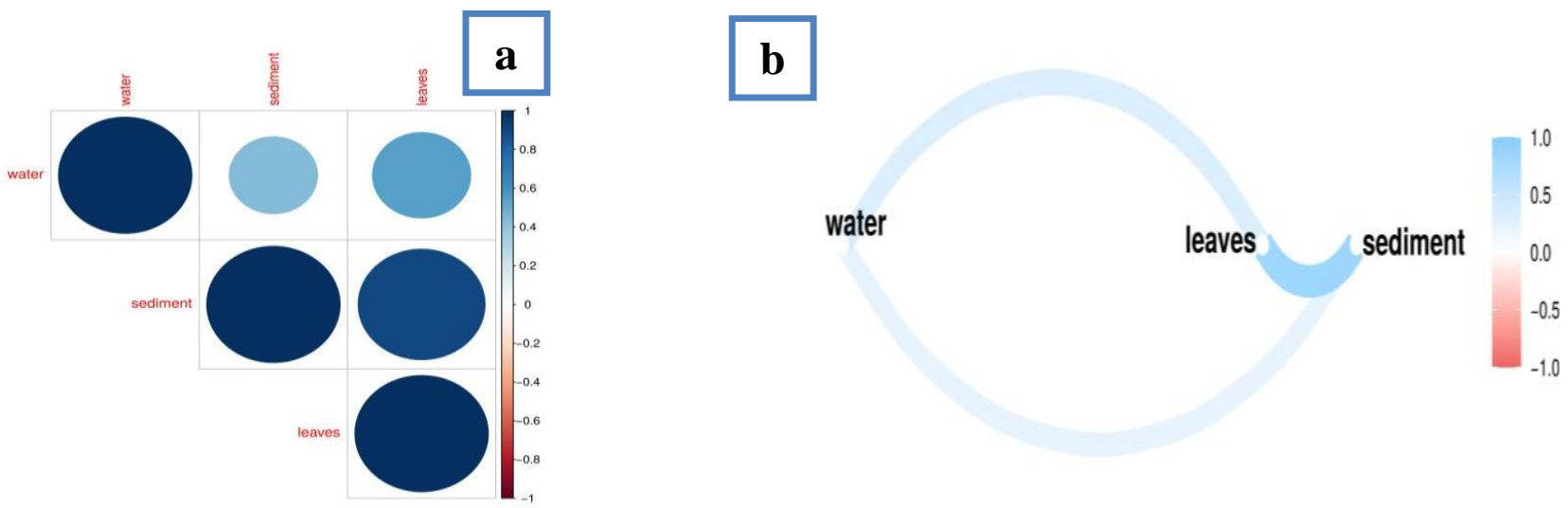

Figure 3: (a) The correlation analysis between water, sediment and leaves count at p-value of 0.05 . (b) Correlation network between water, leaves and sediment at p-value of 0.05 .

The correlation between bacterial count (Figures 4c and 4d) showed that high positive correlation (direct proportion) between Wadi Abu Hamrah- salt peptone agar medium with Se (WH-SPA-with-Se) and $17 \mathrm{Km}$ south Safaga- Nutrient Agar medium-with Se (k17SS-NA-with-Se), 17Km south Safaga-salt peptone agar medium with Se (k17SSSPA-with-Se) and Wadi Abu Hamrah- salt peptone agar medium with Se (WH-SPAwith-Se), and $17 \mathrm{Km}$ south Safaga-Nutrient Agar medium-without Se (k17SS-NAwithout-Se) and Wadi Abu Hamrah-Nutrient Agar medium-without Se (WH-NAwithout-Se). While negative correlation (reverse fit, red color) can be seen between k17SS-SPA-without-Se and k17SS-SPA-with-Se. In this regard, the correlation network showed that, WH-SPA-without-Se, k17SS-SPA-without-Se and WH-SPA-without-Se formed the core of statistical correlation network among other counts. Where any change in these counts could influence changes in the other count.
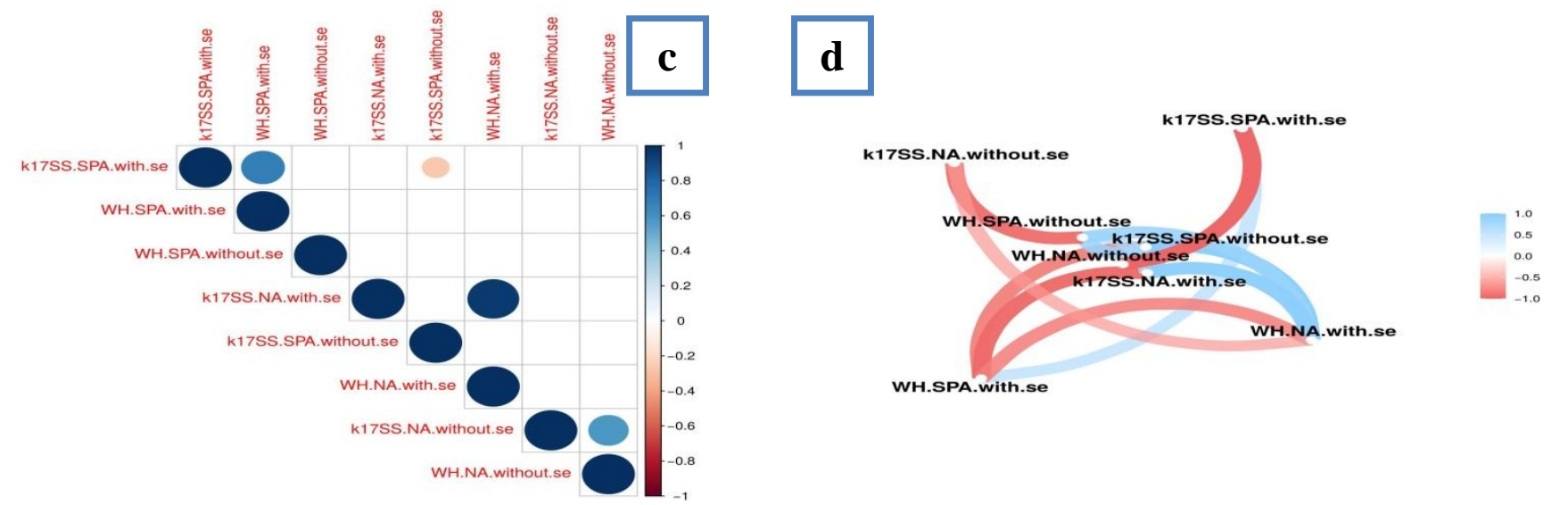

Figure (4): (c) The correlation analysis between bacterial count at p-value of 0.05 and (d) count correlation network at p-value of 0.05. (WH: Wadi Abou Hamrah; k17SS: 17Km Sough Safaga) 


\section{Analytical analysis}

Table (2) displayed different values for Se concentration in the two study areas. Se concentration in the first location (17 Km Sough Safaga) was greater than in the second one (Wadi Abou Hamarah) which explains the difference in counts in both locations as the first location contained higher count than the second. The abundance and activity of bacteria in mangrove ecosystems was attributed to leaf exudates from leaf litter on water (Ashour et al., 2011).

Table (2): values in both sites (location 1; $17 \mathrm{Km}$ south of Safaga and location 2; $35 \mathrm{~km}$ north of Quseir at Wadi Abou Hamarah)

\begin{tabular}{|cccc|}
\hline Location & Se & Location & Se \\
\cline { 1 - 1 } $\mathbf{1 7}$ Km South Safaga & $\mathbf{m g} / \mathbf{K g}$ & Wadi Abu Hamrah & $\mathbf{m g} / \mathbf{~ K g}$ \\
\hline Sediment & 656.61 & Sediment & 538.73 \\
\hline Water & 17.90 & Water & 11.97 \\
\hline Plant & 419.78 & Plant & 386.54 \\
\hline
\end{tabular}

\section{Characterization of the bacterial isolates:}

In the present study, sixteen bacterial isolates were selected from twenty-six isolates from mangrove water, sediment, and mangrove leaves ecosystem. According to phenotypic characterizations of the bacteria isolated, the entire sixteen isolates were shown to be Gram-negative, spore former, motile, and aerobic rod (Table 3). The growth characterization was performed to evaluate the variation of salt concentration in the media that greatly affects the growth of bacterial strains. It was essential to see the effect of salt concentration on selenite (Se (IV)) reduction (Mishra et al., 2011) using SP medium containing $5 \mathrm{mM}$ sodium selenite.

The bacterial response to different $\mathrm{NaCl}$ concentration showed that the selenite reduction of the strains was marginally affected up to $15 \% \mathrm{NaCl}$ and thereafter sharply declined on further increase of salt concentration. For all 16 isolates, $\mathrm{NaCl}$ optimum was ranged from 1-13\%, most isolates were classified as moderate halophiles and as extreme halotolerant while two of the isolates as haloversatile. Borg et al. (2009) reported that the selenite reduction virtually stopped at $20 \%$ of salt in the media. The reduced activity is primarily due to detrimental effect of the ionic stress on the bacteria at higher salt concentrations which inhibits bacterial growth (Table 4).

$\mathrm{pH}$ is an important parameter that influences the microbial reduction of $\mathrm{Se}(\mathrm{IV})$. It was observed that the reduction of Se (IV) $(5 \mathrm{mM})$ increased with an increase of $\mathrm{pH}$ and attained a maxima in between $\mathrm{pH} 7.0$ and 9.0. Further increase of $\mathrm{pH}$ showed a marginal effect on Se (IV) reduction as shown in (Table 4). The bacterial response to different $\mathrm{pH}$ 
values were ranged from 5 to 10 . It may be noted that the reduction of $\mathrm{Se}$ (IV) to $\mathrm{Se}^{0}$ at neutral to alkaline $\mathrm{pH}$ is similar to the observation of Lortie et al., (1992).

Temperature is another factor that affects the microbial reduction of Se (IV). The bacterial response to different temperature values found that most strains are mesophilic bacteria that preferred temperature between 30 and $37{ }^{\circ} \mathrm{C}$ as shown in (table 4).

As a result of microbial reduction of selenium oxyanions the red elemental selenium particles with either crystalline or amorphous structure were produced (Losi and Frankenberger, 1997 and 1998). Most previous studies on microbial Se (IV) reduction to elemental selenium reported that the product of Se (IV) reduction was spherical selenium nanoparticles (Xu et al., 2018).

Table (3): Morphological and main biochemical characteristics of the bacterial isolates

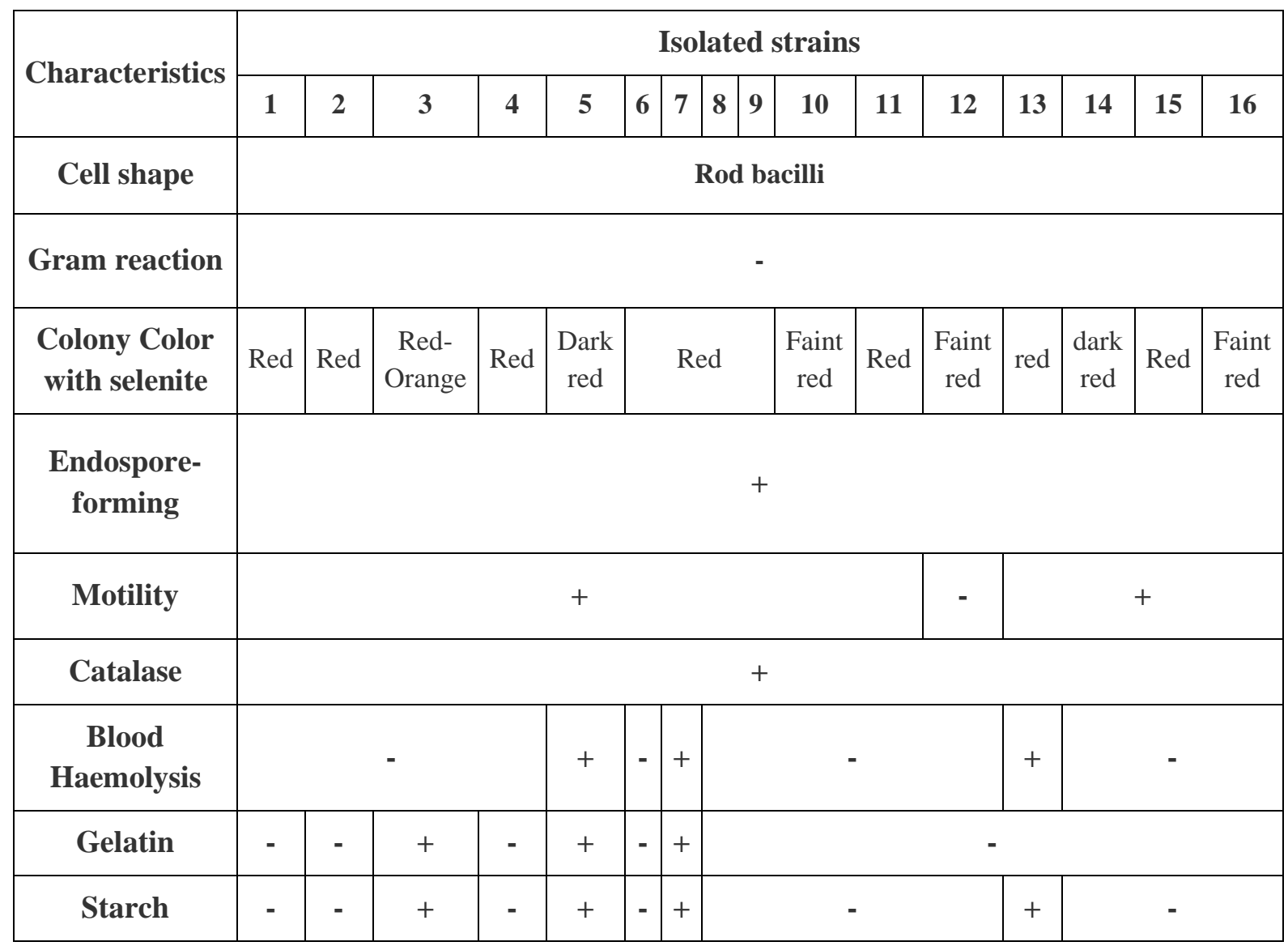


Table (4): Salt, temperature and $\mathrm{pH}$ tolerance values for the sixteen pure bacterial isolates grown in salt peptone broth medium and incubated for $72 \mathrm{hr}$. at $35^{\circ} \mathrm{C}$ in case of salt and pH (Min: Minimum O: Optimum Max: Maximum)

\begin{tabular}{|c|c|c|c|c|c|c|c|c|c|c|c|c|}
\hline \multirow{3}{*}{$\begin{array}{l}\text { Isolate } \\
\text { No. }\end{array}$} & \multicolumn{4}{|c|}{ Salt tolerance } & \multicolumn{4}{|c|}{ Heat toleransce } & \multicolumn{4}{|c|}{ pH tolerance } \\
\hline & \multicolumn{3}{|c|}{ Range (\%) } & \multirow{2}{*}{ Description } & \multicolumn{3}{|c|}{ Range $\left({ }^{\circ} \mathrm{c}\right)$} & \multirow{2}{*}{ Description } & \multicolumn{3}{|c|}{ Range } & \multirow{2}{*}{ Description } \\
\hline & Min & $\mathrm{O}$ & Max & & Min & $\mathrm{O}$ & Max & & Min & $\mathrm{O}$ & Max & \\
\hline 1 & 1 & 5 & 25 & $\begin{array}{l}\text { Extreme } \\
\text { Halotolerant }\end{array}$ & 25 & 30 & 45 & Mesophile & 5 & 6.5 & 10 & Neutrophilic \\
\hline 2 & 1 & 7 & 25 & $\begin{array}{l}\text { Moderate } \\
\text { Halophile }\end{array}$ & 25 & 30 & 45 & Mesophile & 5 & 8 & 10 & Alkalophilic \\
\hline 3 & 1 & 1 & 25 & Halotolerant & 25 & 37 & 45 & Mesophile & 5 & 10 & 10 & Alkalophilic \\
\hline 4 & 1 & 5 & 25 & $\begin{array}{l}\text { Extreme } \\
\text { Halotolerant }\end{array}$ & 25 & 37 & 45 & Mesophile & 5 & 9.5 & 10 & Alkalophilic \\
\hline 5 & 1 & 5 & 25 & $\begin{array}{l}\text { Extreme } \\
\text { Halotolerant }\end{array}$ & 25 & 37 & 45 & Mesophile & 5 & 7.5 & 10 & Alkalophilic \\
\hline 6 & 1 & 7 & 25 & $\begin{array}{l}\text { Moderate } \\
\text { Halophile }\end{array}$ & 25 & 37 & 45 & Mesophile & 5 & 8 & 10 & Alkalophilic \\
\hline 7 & 1 & 3 & 25 & Haloverstile & 25 & 30 & 45 & Mesophile & 5 & 7.5 & 10 & Alkalophilic \\
\hline 8 & 1 & 5 & 25 & $\begin{array}{l}\text { Extreme } \\
\text { Halotolerant }\end{array}$ & 25 & 30 & 45 & Mesophile & 5 & 9.5 & 10 & Alkalophilic \\
\hline 9 & 1 & 5 & 25 & $\begin{array}{l}\text { Extreme } \\
\text { Halotolerant }\end{array}$ & 25 & 37 & 45 & Mesophile & 5 & 7 & 10 & Neutrophilic \\
\hline 10 & 1 & 13 & 25 & $\begin{array}{l}\text { Moderate } \\
\text { Halophile }\end{array}$ & 25 & 30 & 45 & Mesophile & 5 & 8.5 & 10 & Alkalophilic \\
\hline 11 & 1 & 7 & 25 & $\begin{array}{l}\text { Moderate } \\
\text { Halophile }\end{array}$ & 25 & 37 & 45 & Mesophile & 5 & 7 & 10 & Neutrophilic \\
\hline 12 & 1 & 7 & 25 & $\begin{array}{l}\text { Moderate } \\
\text { Halophile }\end{array}$ & 25 & 30 & 45 & Mesophile & 5 & 7.5 & 10 & Neutrophilic \\
\hline 13 & 1 & 3 & 25 & Haloverstile & 25 & 30 & 45 & Mesophile & 5 & 8 & 10 & Alkalophilic \\
\hline 14 & 1 & 5 & 25 & $\begin{array}{l}\text { Extreme } \\
\text { Halotolerant }\end{array}$ & 25 & 37 & 45 & Mesophile & 5 & 7.5 & 10 & Alkalophilic \\
\hline 15 & 1 & 5 & 25 & $\begin{array}{l}\text { Extreme } \\
\text { Halotolerant }\end{array}$ & 25 & 30 & 45 & Mesophile & 5 & 7.5 & 10 & Alkalophilic \\
\hline 16 & 1 & 10 & 25 & $\begin{array}{l}\text { Moderate } \\
\text { Halophile }\end{array}$ & 25 & 30 & 45 & Mesophile & 5 & 8.5 & 10 & Alkalophilic \\
\hline
\end{tabular}


Transmission electron microscopy (TEM) and scanning electron microscopy (SEM) analysis to determine selenium particle within isolate cell

Figure (5) shows the characterized reduced product (elemental selenium $\mathrm{Se}^{0}$ ) associated with the cell, by SEM and TEM showed in (Fig.5). SEM and TEM microphotographs of the elemental selenium revealed globular both outside and inside the bacterial cells in the media. SEM analysis revealed the formation of $\mathrm{Se}^{0}$ nanoparticles around the elongated bacterial cell. Further analysis by TEM revealed the formation of nanospheres through the reduction of Se (IV) by different bacterial strains. Also, Yee et al. (2007) reported similar observation indicating the ability of the bacteria to accumulate Se around and inside cells.
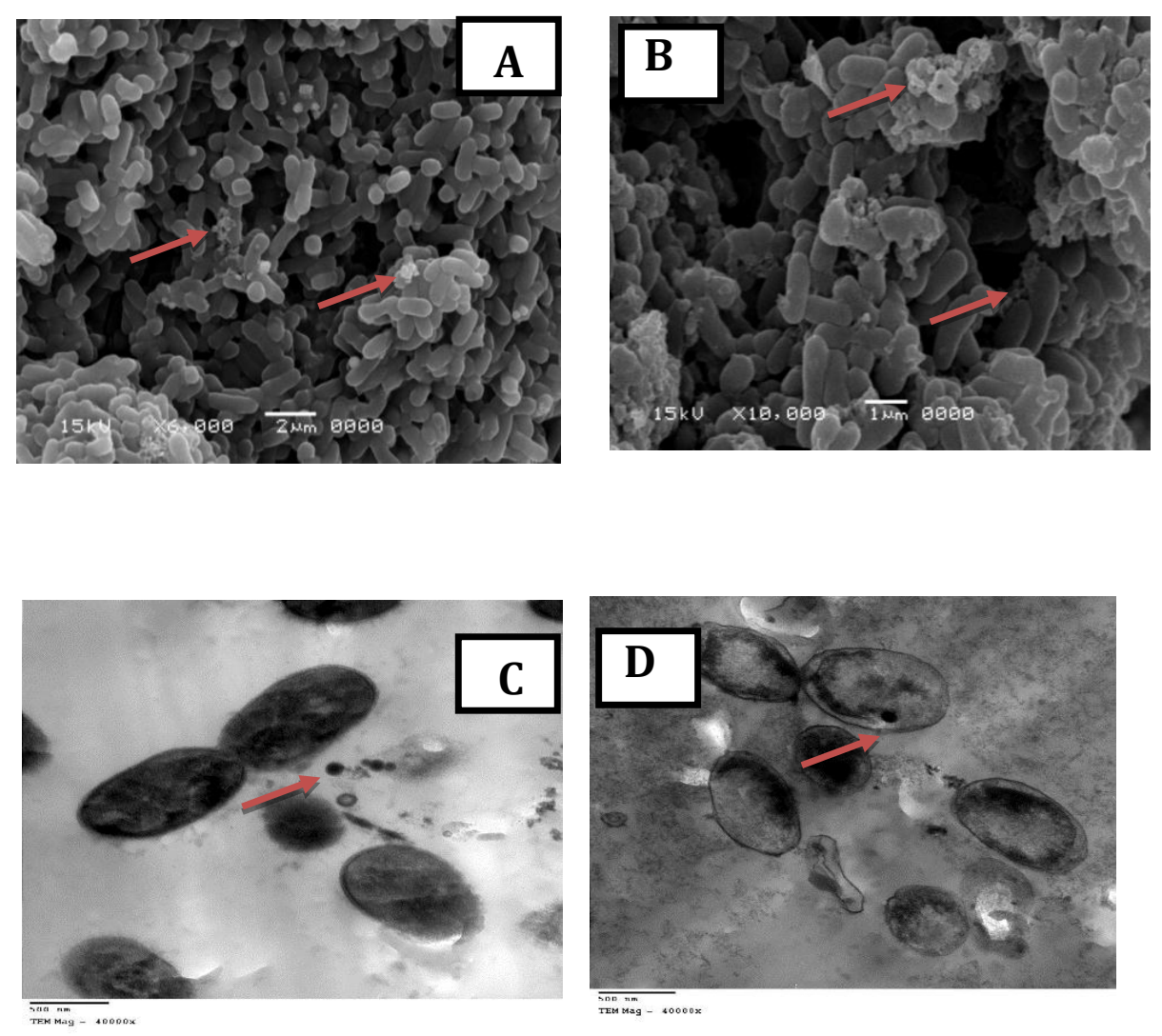

Figure (5): TEM and SEM micrographs of Cobetia amphilecti (A\&C) and Vibrio alginolyticus (B \&D) exposed to5 $\mathrm{mM}$ selenite obtained after $72 \mathrm{~h}$ of growth. The arrows indicate the presence of spherical selenium particales outside and inside the cells. 


\section{For 16srRNA sequences of the two selected isolates}

The NCBI-Blast analysis was successfully used to identify strains 2 and 3.16S DNA sequences annotation and their corresponding species. The NCBI-Blast tool assigned strain 2 to Cobetia amphilecti MSN1517 with similarity score $97.5 \%$ and sequence coverage of $96 \%$ and strain 3 as Vibrio alginolyticus MSN1517 with similarity score 95 $\%$ and sequence coverage of 95\% (Fig. 6) with accession numbers of MN099349 and MN099350 for strains 2 and 3, respectively.
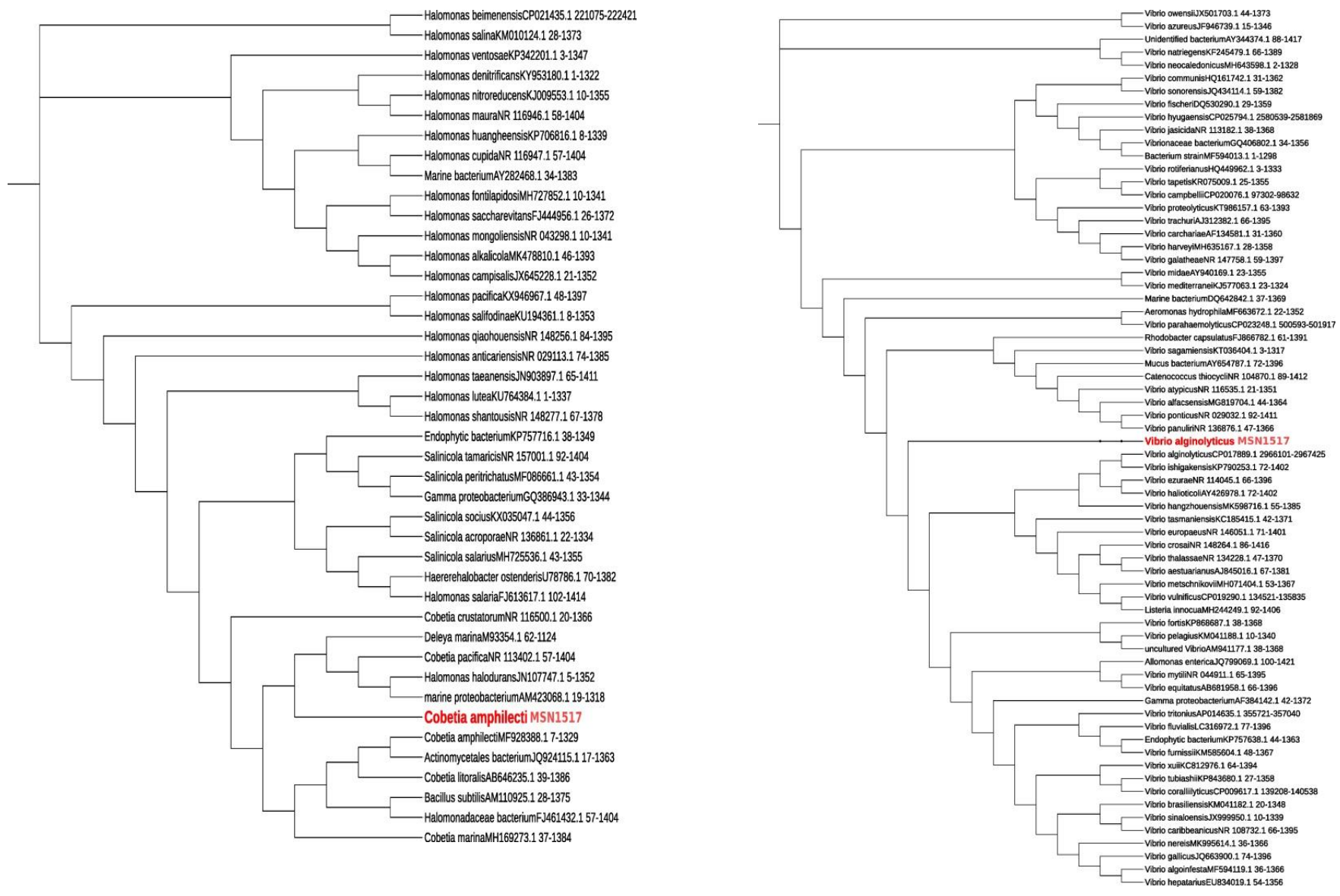

Figure (6): the phylogenetic tree constructed using 16S DNA sequences, where the isolates MSN1517 obtained form was Cobetia amphilecti and Vibrio alginolyticus highlighted.

\section{Digital elevation model}

DEM help in the extraction of the drainage network at the two study areas. Drainage pattern showing that there are different drains that pour directly in mangrove stands in both study areas especially in South Safaga stand which connected with main drain that might be a source of many elements and metals including selenium in mangrove ecosystem (Figs. 7a and b). 

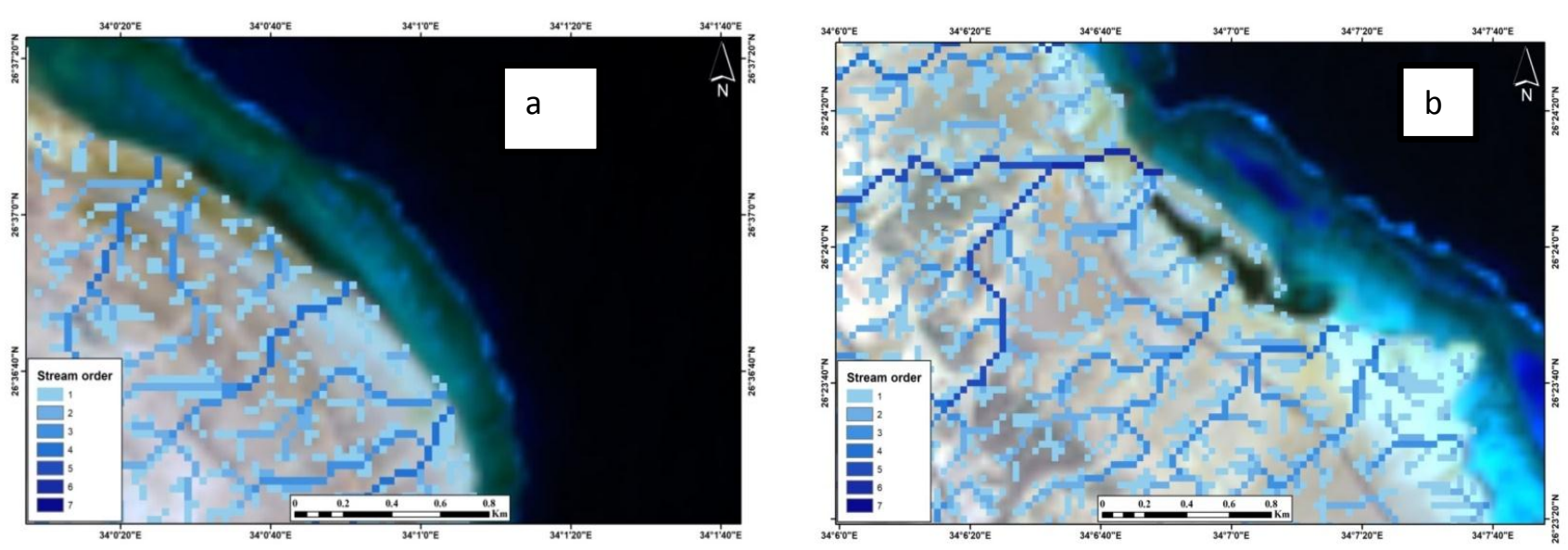

Figure (7): (a) Drainage network at South Safaga stand, (b): at Wadi Abu Hamrah stand

\section{CONCLUSION}

Selenium exists in the environment due to natural and anthropogenic activities that increased the contamination risk to the ecosystem. Conventional chemical methods for removing toxic oxyanions are expensive and require high energy or large quantities of chemical reagents, while microbial reduction of these toxic oxyanions is cost effective and supports green technology. In the current study, sixteen of selenite reducing microbial isolates showed potential to bioremediate the toxic form of selenium into less toxic form in a cost effective way. Two of these isolates well characterized halotolerant (Cobetia amphilecti and Vibrio alginolyticus) isolated from saline mangrove habitat, were found capable of reducing Selenite to elemental selenium even in the presence of high salt concentrations. Under optimized set of conditions (at $30-37^{0} \mathrm{C}$, initial $\mathrm{pH}$ 9.5-8) almost complete reduction of Se (IV) $5 \mathrm{mM}$ was achieved within $48-72 \mathrm{~h}$ incubation. This selenite reducing bacteria were not detected and /or isolated from Red Sea Egyptian coast before, and the both identified strains are novel and well-characterized bacterial aerobic selenite reductase.

\section{REFERENCES}

Afkar E.; Lisak J.; Saltikov C.; Basu P.; Oremland RS.; Stolz JF. (2003). The respiratory arsenate reductase from Bacillus selenitireducens strain MLS10. FEMS Microbiol Lett 226:107-112.

American Public Health Association (APHA) (1995). Standard methods for the examination of water and waste water 19th (ed). American Public Health Association, Washington, D.C. 
American Public Health Association (APHA) (2017). Standard methods for the examination of water and waste water $23^{\text {rd }}$ (ed). American Public Health Association, Washington, D.C.

Ashour, S.M.; Mostafa, S.A.; Ahmed, H.H. (2011). Halophilic and halotolerant bacteria in mangrove ecosystem south Safaga on the Red Sea, Egypt, African J. Biol. Sci., 7 (1): 61-68.

Balasubramanian, (2017). Digital Elevation Model (DEM) in GIS. University of Mysore,https://www.researchgate.net/publication/319454004_DIGITAL_ELEVATION MODEL_DEM_IN_GIS).

Basheer, M. A.; El Kafrawy, S. B.; \& Mekawy, A. A. (2019). Identification of mangrove plant using hyperspectral remote sensing data along the Red Sea, Egypt. Egyptian Journal of Aquatic Biology and Fisheries, 23(1): 27-36.

Borg, C; Friese, D; Yin, T.T. (2009). Removal of Selenium in Contaminated Wastewater Streams. US patent 2009/0152194A1.

Chen, W and Liu, Y. (2013). Isolation and Identification of Halomonas sp. ZSCW-10: a Moderately Halophilic Bacteria Strain with Cellulase Activity, Advanced Materials Research Vol 749, pp 236-241.

David N; Gluchowski DC; and Leatherbarrow JE. (2015). Estimation of contaminant loads from the Sacramento- San Joaquin river delta to San Francisco Bay. Water.Environ. Res; 87:334-346.

Fordyce F. (2005). Selenium deficiency and toxicity in the environment. In: Selinus, O. (ed) Essent. Med. Geol.373-415.

Gonzalez-Gil G.; Lens PNL.; and Saikaly PE. (2016) .Selenite Reduction by Anaerobic Microbial Aggregates: Microbial Community Structure, and Proteins Associated to the Produced Selenium Spheres. Front. Microbiol. 7:571. doi: 10.3389/fmicb.2016.00571

Hedi, A.; Sadafi, N.; Fardeau, M.L.; Rebib, H., Cayol J.L.; Ollivier, B.; and Boudabous, A. (2009). Studies on the Biodiversity of Halophilic Microorganisms Isolated from El_Djerid Salt Lake (Tunisia) under Aerobic Conditions, Int. J. Microbiol., article ID 731786, pp. 1-17.

Kerkar, S. (2004). Ecology of Hypersaline Microorganisms. In Marine Microbiology: Facets and Opportunities, Ed. By Ramaiah N., Goa: National Institute of Oceanography; pp. 37-47.

Kessi J. (2006). Enzymic systems proposed to be involved in the dissimilatory reduction of selenite in the purple non-sulfur bacteria Rhodospirillum rubrum and Rhodobacter capsulatus. Microbiology 152:731-743.

Khalaf, A.A.A. (2002). Ecological adaptation of Avicennia marina plants growing at Qussier, Red Sea coast, Egypt. Ph.D Thesis. Ain Shams University, Faculty of Girls, Botany Department, Cairo, Egypt. 
Khalilian, M.; Zolfaghari, M.R.; Soleimani , M.; Zand Monfared, M.R. (2015). Bacillus sp. strain QW90, a bacterial strain with a high potential application in bioremediation of selenite. Report of Health Care; 1(1): 6-10.

Letunic, I.; and Bork, P. (2006). Interactive Tree Of Life (iTOL): an online tool for phylogenetic tree display and annotation. Bioinformatics, 23(1), 127-128.

Lortie, L.; Gould, W.D.; Rajan, S.; McCready, R.G.L.; Cheng, K.J. (1992). Reduction of selenate and selenite to elemental selenium by a Pseudomonas stutzeri isolate. Appl. Environ. Microbiol. 58, 4042-4044.

Losi, M.E.; and Frankenberger, W.T. (1998). Reduction of selenium oxyanions by Enterobacter cloacae strain SLD1a-1. In: Frankenberger, W.T., Engberg, R.A. (Eds.), Environmental Chemistry of Selenium. Marcel Dekker, New York, pp. 515-544.

Losi, M.E.; and Frankenberger, W.T. (1997). Reduction of selenium oxyanions by Enterobacter cloacae SLD1a-1: isolation and growth of the bacterium and its expulsion of selenium particles. Appl. Environ. Microbiol. 63, 3079-3084.

Metsalu T.; and Vilo J. (2015). ClustVis: a web tool for visualizing clustering of multivariate data using Principal Component Analysis and heatmap. Nucleic Acids Res.; 43(W1): W566-W570. doi: 10.1093/nar/gkv468.

Mishra, R.R.; Prajapati, S.; Das, J.; Dangar, T.K.; Das, N.; Thatoi, H. (2011). Reduction of selenite to red elemental selenium by moderately halotolerant Bacillus megaterium strains isolated from Bhitarkanika mangrove soil and characterization of reduced product. Chemosphere.84: 1231-1237.

Montes, R. A. (2012). The bacterial toxicity of selenocyanate and the incorporation of tellurium and selenium in bacterial cells, and the synthesis and biosynthesis of cadmium telluride nanoparticles and their elemental quantification via ICP-AES (Doctoral dissertation, Sam Houston State University).

Nancharaiah YV.; and Lens PNL (2015). Ecology and biotechnology of seleniumrespiring bacteria. Microbiol Mol Biol Rev 79:61-80.

Pham.T.D.; Yokoya.N.; Bui.D.T.; Yoshino.K.; and Friess.D.A. (2019). Remote Sensing Approaches for Monitoring Mangrove Species, Structure, and Biomass: Opportunities and Challenges. Remote Sens. 11, 230:1-24.

Pierru B.; Grosse S.; Pignol D. (2006). Genetic and biochemical evidence for the involvement of a molybdenum-dependent enzyme in one of the selenite reduction pathways of Rhodobactersphaeroides f. sp. denitrificansIL106. Appl. Enviorn. Microbiol; 72:3147-3153.

Rehan.M.; Alsohim.A.S.; El-Fadly.G.; and Tisa.L.S. (2018). Detoxification and reduction of selenite to elemental red selenium by Frankia. Antonie van Leeuwenhoek. $1-13$. 
Sarika, P. R. (2005). Biogeoorganics and trace metal speciation in mangroves.PhD. thesis, department of chemical oceanography, Cochin University of Science and Technology.

Savard, D.; Be'dard L.P.; Barnes S.J. (2009). Selenium concentrations in twenty-six geological reference materials: new determinations and proposed values. Geostand Geoanal Res 33:249-259.

Thi.V.T.; Xuan.A.T.T.; Nguyen.H.P.; Guebas.F.D.; and Koedam.N. (2014). Application of remote sensing and GIS for detection of long-term mangrove shoreline changes in Mui Ca Mau, Vietnam. Biogeosciences.11, 3781-3795.

Twilley, R.R.; Chen, R.; and Hagis, A. (1992). Carbon sinks in mangrove and their implication to carbon budget of tropical coastal ecosystem. Water, Air and Soil Pollution, 64: 265-288.

Ventosa, A. (2004). Halophilic Microorganism (P. 349pp), Berlin; Springer.

Williams, S.T.; Sharpe, M.E.; and Holt, J.T. (1989). Bergey's Manual of Determinative Bacteriology, vol.4, Williams and Wilkins, Baltimor.

Xu, D.; Yang, L.; Wang, Y.; Wang, G.; Rensing, C.; Zheng, S. (2018). Proteins enriched in charged amino acids control the formation and stabilization of selenium nanoparticles in Comamonas testosteroni S44. Sci. Rep. 8, 4766. https://doi.org/10.1038/ s41598-018-23295-5.

Yee, N.; Ma, J.; Dalia, A.; Boonfueng, T.; Kobayashi, D.Y. (2007). Se (VI) reduction and the precipitation of $\mathrm{Se}(0)$ by the facultative bacterium Enterobacter cloacae SLD1a-1 are regulated by FNR. Appl. Environ. Microbiol. 73, 1914-1920.

Zhang, J.; Wang, Y.; Shao, Z.; Li, J.; Zan, S.; Zhou, S.; \& Yang, R. (2019). Two selenium tolerant Lysinibacillus sp. strains are capable of reducing selenite to elemental Se efficiently under aerobic conditions. Journal of environmental sciences (China), 77, 238-249. https://doi.org/10.1016/j.jes.2018.08.002. 


\author{
الملخص العربحى \\ دمج التكنولوجيا الجغرافية المكانية مع علم الأحياء الدقيقة في عزل ووصف البكتريا المختزلة للسيلينيت من

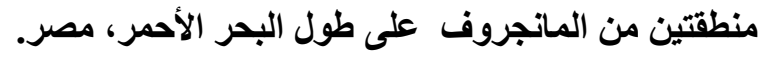 \\ سعاد حسن شتلة'، سامح بكر الكفر اوي، هالة عبد المنعم أحمد1، مهرشان طه المقدم1 \\ 1- قسم النباتـ كليه البنات للاداب و العلوم و التربية- جامعة عين شمس \\ 2- قسم علوم البحار - الهيئة القومية للإستشعار من بعد و علوم الفضاء
}

يمثل الاستخدام الواسع لمركبات السيلينيوم المصدر الرئيسي للتلوث بالسيلينيوم في جميع أنحاء العالم مسببا مشاكل

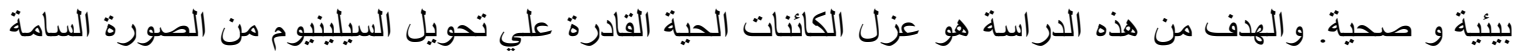

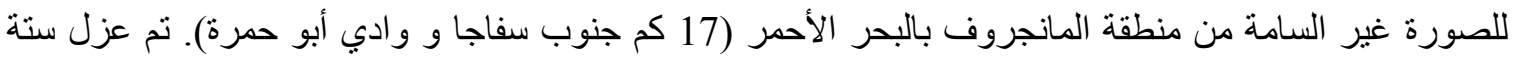

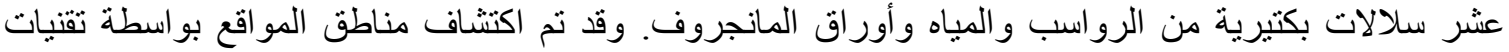

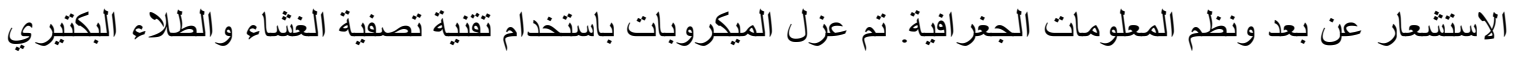

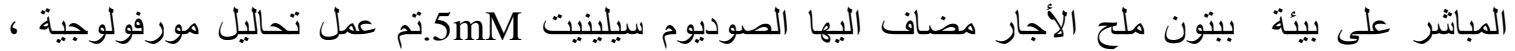

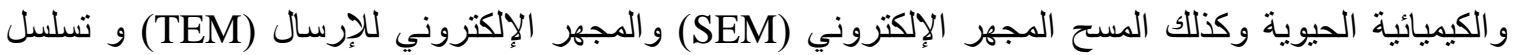
الجينات 16S rRNA لاثنين من هذة العزلات.أوضحت النتائج أن البكتريا المعزولة قادرة علي اختزال الصوديوم

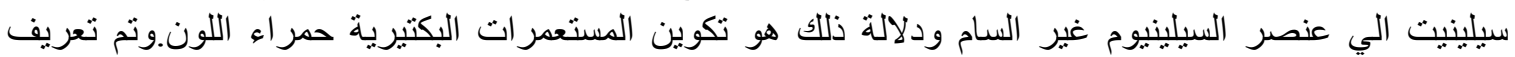

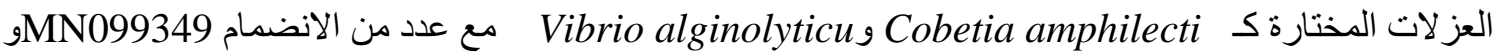

.MN099350

وأكدت تحاليل TEM SEM علي تكوين أجسام كروية من عنصر السيلينيوم غير قابل للذوبان داخل وخارج

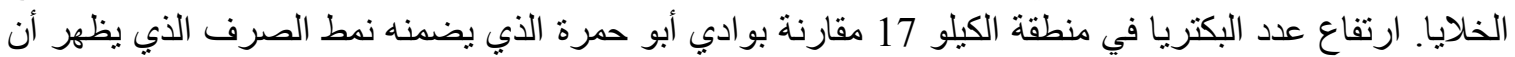

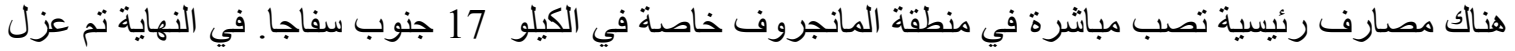

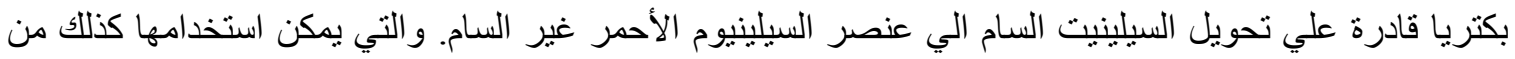
أجل الإصلاح البيولوجي للمو اقع الملوثة. علي حد علمنا انه لم يتم عزل هذة البكتريا من ساحل البحر الاحمر بمصر من قبل و تعتبر البكتريا المعرفة جينيا جديدة. 